\title{
Physiological energetics of the horse mussel Modiolus modiolus in a cold ocean environment
}

\author{
J. M. Navarro*, R. J. Thompson \\ Ocean Sciences Centre, Memorial University of Newfoundland, St. John's, Newfoundland, Canada A1C 5S7
}

\begin{abstract}
A population of Modiolus modiolus (horse mussel) inhabiting a sub-arctic environment in Logy Bay, Newfoundland, Canada, was studied for 2 yr. The main objective was to gain insight into the relationship between environmental factors (temperature and components of the seston) and the physiological response of this species. The highest values for energy acquisition (ingestion and absorption rates) by $M$. modiolus coincided with the spring phytoplankton bloom occurring during April-May in Logy Bay, whereas energy expenditure (oxygen uptake and ammonia excretion rate) was greatest during the summer (July and August). The result was a clear seasonal fluctuation in the 2 physiological integrations, scope for growth (SFG) and net growth efficiency $\left(K_{2}\right)$, for which lower values were associated with a high metabolic rate, high temperature and low quality of the food supply. Conversely, higher values of SFG and $K_{2}$ were associated with a low metabolic rate, low temperature and an energy-rich food supply provided by the phytoplankton bloom. $M$. modiolus appears to be a species which is able to compensate physiologically for the poor food conditions occurring in Logy Bay during a large part of the year. It does this by reducing feeding activity during fall and winter, when there is a poor food supply. Conversely, it increases clearance rate during spring and early summer, when the seston is mainly composed of phytoplankton. Furthermore, $M$. modiolus has a high absorption efficiency, which may be an adaptation to the low seston concentration in Logy Bay. Such physiological compensations minimise the periods during which SFG is negative, and enable the horse mussel to survive in an environment characterised by an intermittent and of ten inadequate food supply.
\end{abstract}

KEY WORDS: Modiolus modiolus - Horse mussel Physiology - Energetics - Low temperature

\section{INTRODUCTION}

Suspension feeding bivalves are of considerable importance as primary consumers in many marine systems and play a significant role in energy transfer between trophic levels. These organisms frequently occur at high densities and can therefore remove and store large amounts of organic matter in the form of body tissue. Furthermore, they possess highly efficient filtering mechanisms which enable them to concentrate large amounts of suspended particles from the pelagic system and reject some of this energy-rich material as faeces or pseudofaeces, which reach the bottom, where they can be utilised as food by other organisms.

\footnotetext{
- Present address: Instituto de Biología Marina, Universidad Austral de Chile, Casilla 567, Valdivia, Chile.

E-mail: jnavarro@valdivia.uca.uach.cl
}

Several researchers have determined individual physiological functions and the integrated responses of many species of marine bivalves. Bayne et al. (1976) and Bayne \& Newell (1983) have reviewed this literature, which is mostly concerned with measurements made under laboratory conditions, often with algal monocultures as food. Results from such studies may not be representative of the natural situation, and more authors are placing emphasis on measurements of physiological rates under natural conditions, preferably in the field Bayne \& Widdows 1978, Widdows 1978, Newell \& Bayne 1980, Vahl 1980, Thompson 1984, MacDonald \& Thompson 1986).

Feeding rate is often strongly associated with food availability, and recent theoretical explanations of feeding by suspension and deposit feeders have suggested that the organisms can optimise energy yield when food varies in quality and/or quantity (Taghon 1981, Bayne et al. 1988). Thus the optimal response is 
to increase the feeding rate (or ingestion rate) when an increase in food quality occurs, even when this results in a reduced gut retention time with a consequent decline in absorption efficiency (AE). Bayne et al. (1984) reported that individuals of Perna perna from South Africa feeding on low-quality diets show reduced clearance rates (CR), slower gut passage rates and higher values of AE. Conversely, this species shows higher $C R$, rapid passage of food through the gut, and reduced $A E$ at higher food concentrations. However, when calculated on a daily basis the absorbed ration is very similar for the 2 different diets, showing that the physiological flexibility to maximise scope for growth (SFG) is mainly based on balances between $C R$, residence time in the gut, and $A E$.

The horse mussel Modiolus modiolus is abundant on rocky sublittoral substrates along the Atlantic coasts of North America and northern Europe. It is often longlived, and many populations contain individuals older than $35 \mathrm{yr}$ (Anwar et al. 1990). In the Bay of Fundy, Canada, $M$. modiolus is a dominant species on hard subtidal substrates (Logan 1988). In the Gulf of Maine, USA, $M$. modiolus is a foundation species of the rocky subtidal community and occupies a lot of space to form stable, persistent beds at depths of 18 to $30 \mathrm{~m}$; these beds withstand biological disturbance and provide a refuge from predation for the associated diverse invertebrate community which they harbour (Witman 1985). Biodeposits from horse mussels also accumulate at the bases of the clumps and provide a suitable environment for deposit feeders such as polychaetes (Brown \& Seed 1977, Witman 1985, Ojeda \& Dearborn 1989). Beds of $M$. modiolus may also be colonised by those suspension-feeders (e.g. ophiuroids, tunicates and barnacles) that are associated with turbulent and slow current conditions such as those found within aggregations of mussels (Ojeda \& Dearborn 1989).

In view of the ecological importance of the suspension-feeder Modiolus modiolus, we wished to establish its physiological response to changing environmental conditions in order to gain insight into trophic interactions in this benthic ecosystem. A detailed analysis of the energy budget of $M$. modiolus may provide a means of understanding the effects of seasonal environmental changes (mainly seston) on the degree of physiological plasticity and adaptation of the horse mussel to its environment. There is very little information on this species, apart from some measurements of SFG (Lesser et al. 1994) and some evidence that $M$. modiolus has a different growth and reproductive investment strategy than the better known Mytilus edulis. In particular, the growth rate of the horse mussel is slower (Rowell 1967, Anwar et al. 1990) and the repraductive cycle is not discrete (Seed \& Brown 1977). The objective of the present paper is to determine the physiological response of $M$. modiolus to short-term (hours) and long-term (seasonal) changes in temperature and food supply in the natural environment, in this case the cold coastal waters of Newfoundland, Canada (Navarro \& Thompson 1995). For this purpose, an analysis of size-related oxygen uptake rate $\left(\mathrm{VO}_{2}\right), \mathrm{CR}$, $\mathrm{AE}$ and rate of ammonia excretion $\left(V \mathrm{NH}_{4}-\mathrm{N}\right)$ was carried out in $M$. modiolus from Logy Bay, southeastern Newfoundland, during 1986-1988. Two physiological indices, SFG and net growth efficiency $\left(K_{2}\right)$, were then derived to describe the integrated response of the whole organism to environmental changes.

\section{MATERIAL AND METHODS}

Experimental animals. Specimens of Modiolus modiolus were collected approximately monthly (1986-1988) by SCUBA divers at 15 to $20 \mathrm{~m}$ depth from a rock face in Logy Bay, Newfoundland, near the seawater intake of the Ocean Sciences Centre. The mussels were immediately transported to the laboratory, cleaned of any epibiota, and held in flowing unfiltered seawater under ambient conditions of temperature, salinity and seston.

For each collection, 15 mussels covering a wide size range ( 3 to $12 \mathrm{~cm}$ shell length) were selected for physiological experiments. For comparisons between experiments, and to calculate SFG for mussels of standard weight, physiological rates were standardised to 1,2 and $5 \mathrm{~g}$ dry tissue weight using the following formula:

$$
Y_{\mathrm{s}}=\left(W_{\mathrm{s}} / W_{\mathrm{e}}\right)^{b} \times Y_{\mathrm{e}}
$$

where $Y_{\mathrm{s}}=$ physiological rate for an individual of standard weight, $W_{\mathrm{s}}=$ standard weight of individual, $W_{\mathrm{e}}=$ observed weight of individual, $Y_{e}=$ uncorrected (measured) physiological rate, $b=$ weight exponent for the physiological rate function, determined from the regression equation for the appropriate sampling date.

Clearance rate. Seawater was pumped directly from the ocean into a mixing chamber of constant volume (15 l) with a flow rate high enough to maintain a wellmixed suspension of particulate matter. Each experimental mussel ( $\mathrm{n}=15$ ) was placed in a plastic container $(0.81$ capacity), and flow rates of 60 to $200 \mathrm{ml}$ min $^{-1}$ were supplied from the mixing chamber, depending on the size of the mussel. Thus the reduction in particle concentration between inflow and outflow was kept between 20 and $40 \%$, eliminating the possibility of recirculation through the mantle cavity of the mussel. One additional container with the same flow rate, but with no mussel, served as a control. The experimental mussels were left undisturbed for at least 
$12 \mathrm{~h}$ before the CR measurements were begun. Measured volumes of water were simultaneously collected from each overflow in a given period of time to determine the flow rate, and a Coulter Counter Model ZB fitted with a $100 \mu \mathrm{m}$ orifice tube was used to determine the difference between the particle concentration in the inflow (control value) and the outflow from each container.

Clearance rate $\left(\mathrm{h} \mathrm{h}^{-1}\right)$ was calculated using the formula:

$$
\mathrm{CR}=\left(\frac{C_{1}-C_{2}}{C_{1}}\right) \times \mathrm{F}
$$

where $C_{1}=$ inflow particle concentration (particles $\mathrm{ml}^{-1}$ ), $C_{2}=$ outflow particle concentration (particles $\left.\mathrm{ml}^{-1}\right), \mathrm{F}=$ flow rate through the chamber $\left(\mathrm{l} \mathrm{h}^{-1}\right)$.

Clearance rate experiments were run for 12 to $24 \mathrm{~h}$ and mean values of several consecutive measurements ( 8 to 15 ) calculated, including zero values when the mussel was not feeding.

Ingestion rate. Ingestion rate was calculated as the product of clearance rate $\left(\mathrm{l} \mathrm{h}^{-1}\right)$ and the concentration of suspended particulate matter (SPM) (mg $\mathrm{l}^{-1}$ ), determined by Navarro \& Thompson (1995). Ingested ration ( $\mathrm{mg} \mathrm{h}^{-1}$ ) was converted to energy equivalents using the conversion factors $1 \mathrm{mg}$ protein $=24.0 \mathrm{~J} ; 1 \mathrm{mg}$ carbohydrate $=17.5 \mathrm{~J} ; 1 \mathrm{mg}$ lipid $=39.5 \mathrm{~J}$ (Gnaiger 1983) .

Absorption efficiency. At the end of each series of CR measurements, faeces produced by individual mussels were collected with Pasteur pipettes and filtered by vacuum onto precombusted $\left(450^{\circ} \mathrm{C}\right)$, weighed Whatman GF/C filters $(2.5 \mathrm{~cm}$ diameter). Care was taken to exclude pseudofaeces, which were only produced by mussels collected in April. Three water samples from the mixing chamber were taken during each CR series and filtered as described above. Absorption efficiency was then estimated by the ash ratio technique (Conover 1966), which gives reproducible data for Modiolus modiolus (Navarro \& Thompson 1994).

Oxygen uptake. Oxygen uptake was measured with a polarographic electrode (Radiometer E 5046-0) coupled to a Radiometer PHM71 MK2 acid-base analyser fitted with a PHA934 oxygen module (Widdows 1985). The output signal was monitored continuously on a chart recorder. The water in the respirometer was mixed by placing the latter on a submersible magnetic stirrer. The chamber and stirrer were immersed in a temperature-controlled water bath. All measurements were made at field ambient temperature and natural concentration of SPM, and $\mathrm{pO}_{2}$ was not allowed to fall below $70 \%$ of saturation. Values of $V_{2}\left(\mathrm{ml} \mathrm{O}_{2} \mathrm{~h}^{-1}\right)$ were transformed to energy equivalents $\left(1 \mathrm{ml} \mathrm{O} \mathrm{O}_{2}=\right.$ $20.3 \mathrm{~J}$; Elliot \& Davison 1975).

Ammonia excretion. Ammonia excretion was determined by the phenol-hypochlorite method (Widdows
1985). Horse mussels feeding on natural seston were placed individually in glass beakers containing 0.2 to $1.0 \mathrm{l}$ of filtered $(0.45 \mu \mathrm{m})$ seawater, according to the size of the specimen. One additional beaker containing filtered seawater, but with no mussel, served as a control. Measurements were made at field temperatures using a temperature-controlled incubator. Preliminary experiments indicated that the $V \mathrm{NH}_{4}-\mathrm{N}$ in Modiolus modiolus is almost independent of the increasing concentration of ammonia in the experimental chamber during the first $20 \mathrm{~h}$. Values for $V_{N_{4}}-\mathrm{N}$ were expressed in $\mu \mathrm{g} \mathrm{NH}_{4}-\mathrm{Nh}^{-1}$ and transformed to joules using the conversion factor $1 \mu \mathrm{g} \mathrm{NH}_{4}-\mathrm{N}=0.025 \mathrm{~J}$ (Elliot \& Davison 1975).

Scope for growth and net growth efficiency. Scope for growth, which is a physiological index of energy balance to estimate production (growth + reproduction) by an individual animal, was calculated after converting all the physiological rates to energy equivalents $\left(\mathrm{J} \mathrm{h}^{-1}\right)$ :

$$
\mathrm{SFG}=A-(R+U)
$$

where $A=$ energy absorbed $\left(\mathrm{J} \mathrm{d}^{-1}\right), R=$ oxygen uptake $\left(\mathrm{ml} \mathrm{O}_{2} \mathrm{~d}^{-1}\right) \times 20.3 \mathrm{~J}, U=$ ammonia nitrogen excretion rate $\left(\mu \mathrm{g} \mathrm{NH}_{4}-\mathrm{N} \mathrm{d}^{-1}\right) \times 0.025 \mathrm{~J}$.

Net growth efficiency $\left(K_{2}\right)$ was calculated as follows:

$$
K_{2}=\frac{A-(R+U)}{A}
$$

Statistical analysis. Pearson product-moment correlation and multiple linear regression analyses were carried out following $\log _{10}$ transformation (physiological rates) or arcsine transformation (AE percentage), to reduce the dependence of the sample variance on the mean and to normalise the distribution of the data. The relationships between physiological rates and body weight were described by a series of allometric equations of the form $Y=a X^{b}$, where $Y=$ physiological rate, $X=$ body weight and $a$ and $b$ the fitted parameters. Both variables were transformed to logarithms and the data fitted to a straight line by least squares regression. For most of the physiological rates, data were pooled to provide monthly groups before regression analysis. SYSTAT version 4.0 for the PC was used for all statistiCal analyses.

\section{RESULTS}

\section{Clearance rate}

Clearance rate was determined for individuals of various sizes and was expressed as a function of dry tissue weight on different time scales (diurnal, seasonal), and subsequently related to environmental 

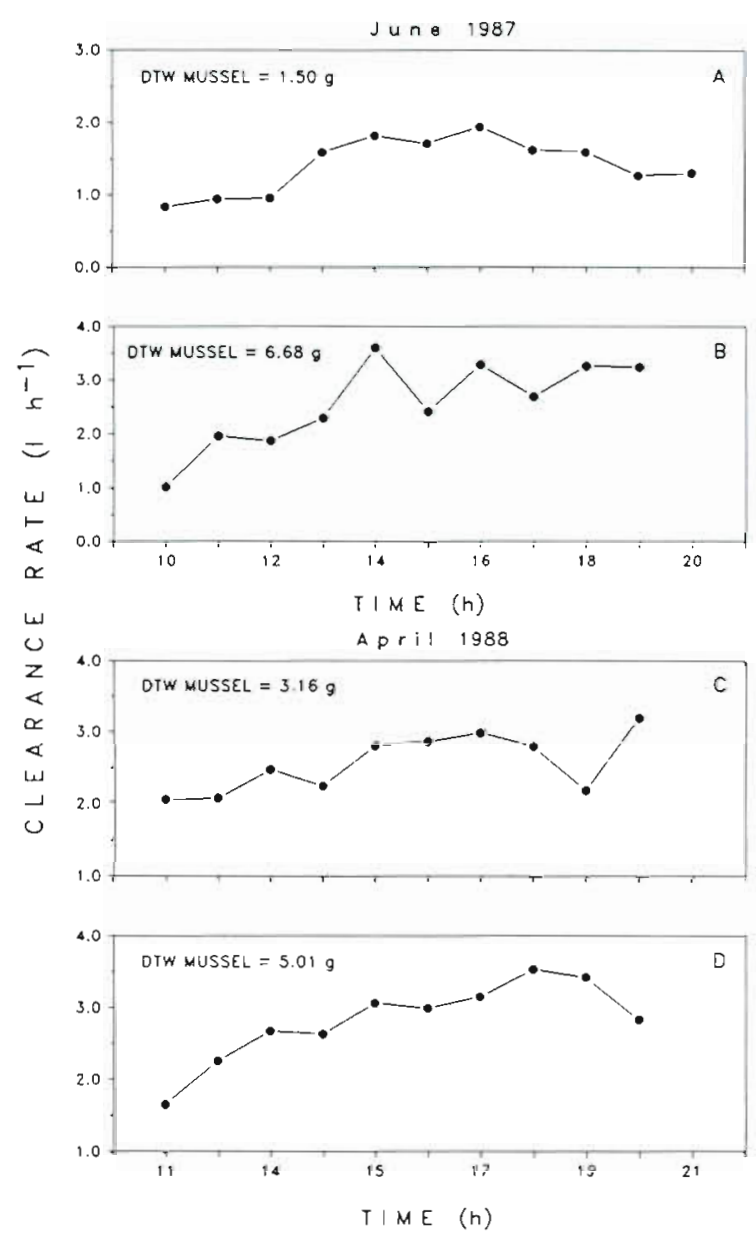

Fig. 1. Modiolus modiolus. Representative short-term patterns of clearance rates for individual horse mussels during (A, B) early summer 1987 and (C, D) spring 1988. DTW: dry tissue weight

conditions. Horse mussels showed periods of high and low $C R$. Higher $C R$ values were characteristic of the spring and early summer, when most of the experimental animals were open and actively feeding most of the time (Fig. 1). In June 1987, for example, CR was maintained in the range 0.84 to $1.95 \mathrm{l} \mathrm{h}^{-1}$ for $10 \mathrm{~h}$ in a mussel of $1.5 \mathrm{~g}$ dry weight (Fig. $1 \mathrm{~A}$ ), whereas an individual of $6.68 \mathrm{~g}$ dry weight showed $\mathrm{CR}$ values between 1.03 and $3.61 \mathrm{l} \mathrm{h}^{-1}$, although most of the values were in the range 2 to $3 \mathrm{l} \mathrm{h}^{-1}$ (Fig. 1B). Similar behaviour was observed in April 1988 (Fig. 1C, D). During fall and especially in winter, $\mathrm{CR}$ in Modiolus modiolus fluctuated widely, with some periods of low and others of high activity (Fig. 2). In November 1986, for example, $\mathrm{CR}$ varied from 0 to $4.38 \mathrm{l} \mathrm{h}^{-1}$ over a period of $12 \mathrm{~h}$ in a mussel of $3.43 \mathrm{~g}$ dry weight (Fig 2A), and from 0 to $2.59 \mathrm{l} \mathrm{h}^{-1}$ in an individual of $3.80 \mathrm{~g}$ dry weight (Fig. 2B). During January, CR was highly variable, and feeding was intermittent (Fig. 2C, D).
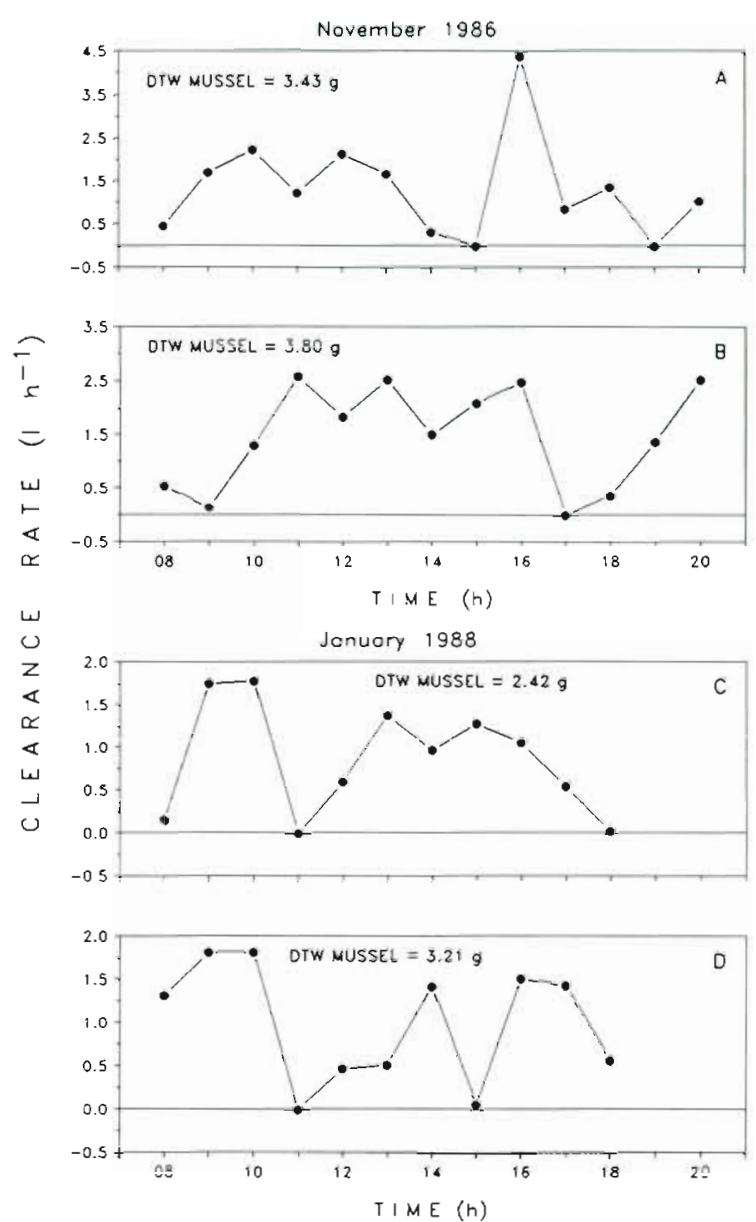

Fig. 2. Modiolus modiolus. Representative short-term patterns of clearance rates for individual horse mussels during (A, B) fall 1986 and (C, D) winter 1988. DTW: dry tissue weight

Clearance rate in Modiolus modiolus showed variation on a seasonal scale as well as short-term variation (Fig. 3). High values were observed during spring-

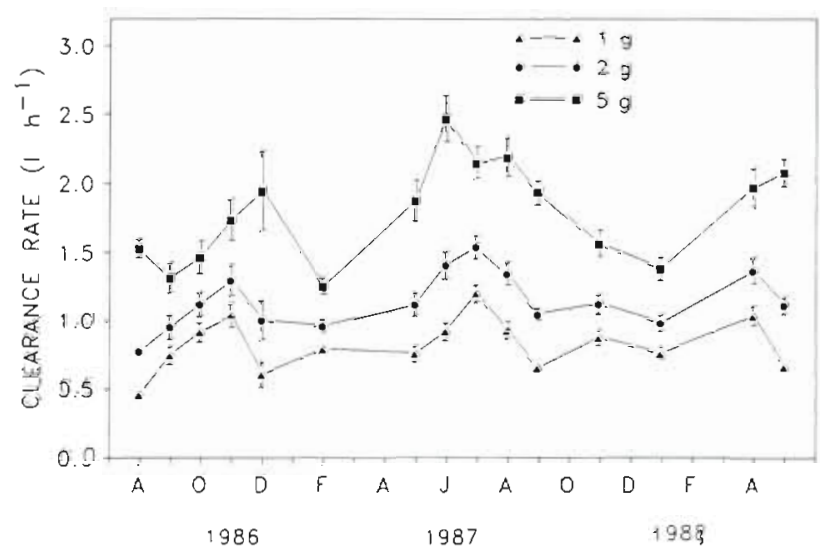

Fig. 3. Modiolus modiolus. Clearance rates in 3 size classes of horse mussel Values are monthly means $\pm \mathrm{SE}$. When no SE bars are shown, they were smaller than the symbols 
summer of 1987 , followed by a decrease in the fall to reach minimum values in winter (February-March). During the fall of 1986, however, CR values increased rather than decreased, which may be attributable to higher and less variable total particulate matter (TPM) values compared with the fall of 1987 (Navarro \& Thompson 1995).

Highly significant regressions were found between CR and dry tissue weight at almost all times of the year (Table 1). Only in September-October 1986 and JulyAugust 1988 were no significant regressions obtained, possibly because a small number of experimental animals was used during these months. When all the data for $C R$ were pooled in one regression equation, this was highly significant $\left(F_{1,178}=197.4\right)$.

Table 1 Modiolus modiolus. Regressions of clearance rate $\left(1 \mathrm{~h}^{-1}\right)$ against dry weight $(\mathrm{g})$ for different dates. Regression equations are of the form $Y=a W^{b}$, where $Y=$ clearance rate and $W=$ dry weight. The statistic $F$ tests the significance of the difference between $b$ and zero. "Significant at $p \leq 0.05$; $\because$ significant at $p \leq 0.01$; ${ }^{\text {ns }}$ not significant

\begin{tabular}{|c|c|c|c|c|c|}
\hline Date & $\mathrm{n}$ & $a$ & $b$ & r & $F$ \\
\hline Aug 1986 & 10 & 0.48 & 0.73 & 0.90 & $32.0^{\circ}$ \\
\hline Sep 1986 & 10 & 0.73 & 0.36 & 0.51 & $2.8^{n s}$ \\
\hline Oct 1986 & 8 & 0.90 & 0.28 & 0.59 & $3.2^{n_{3}}$ \\
\hline Nov 1986 & 9 & 1.01 & 0.32 & 0.74 & $8.3^{\circ}$ \\
\hline Dec 1986 & 10 & 0.56 & 0.72 & 0.71 & $7.9^{\circ}$ \\
\hline Feb 1987 & 14 & 0.78 & 0.29 & 0.77 & $17.2^{*}$ \\
\hline May 1987 & 8 & 0.75 & 0.56 & 0.91 & $28.0^{\circ}$ \\
\hline Jun 1987 & 14 & 0.89 & 0.61 & 0.88 & $42.3^{\circ}$ \\
\hline Jul 1987 & 14 & 1.17 & 0.36 & 0.80 & $21.8^{\circ}$ \\
\hline Aug 1987 & 15 & 0.91 & 0.53 & 0.87 & $41.9^{\circ}$ \\
\hline Sep 1987 & 14 & 0.66 & 0.67 & 0.92 & $66.1{ }^{\prime} \cdot$ \\
\hline Nov 1987 & 14 & 0.86 & 0.35 & 0.71 & $12.2^{*}$ \\
\hline $\operatorname{Jan} 1988$ & 12 & 0.75 & 0.37 & 0.72 & $10.9^{\circ}$ \\
\hline Apr 1988 & 14 & 1.02 & 0.39 & 0.57 & $5.6^{\circ}$ \\
\hline May 1988 & 14 & 0.66 & 0.71 & 0.90 & $51.8 \cdot$ \\
\hline Jul 1988 & 5 & 0.66 & 0.75 & 0.57 & $1.5^{\mathrm{ns}}$ \\
\hline Aug 1988 & 5 & 0.72 & 0.64 & 0.56 & $1.4^{\mathrm{ns}}$ \\
\hline Pooled data & 180 & 0.85 & 0.46 & 0.73 & $197.4{ }^{\circ}$ \\
\hline
\end{tabular}

\section{Ingestion rate}

Values for ingestion rate (IR) were greatest during the spring (Fig. 4), reflecting higher clearance rates (this study) as well as more particulate organic matter (POM) during the phytoplankton bloom in both years (Navarro \& Thompson 1995).

\section{Absorption efficiency}

Absorption efficiency varied seasonally in an inconsistent manner, ranging from 50.3\% in November 1986

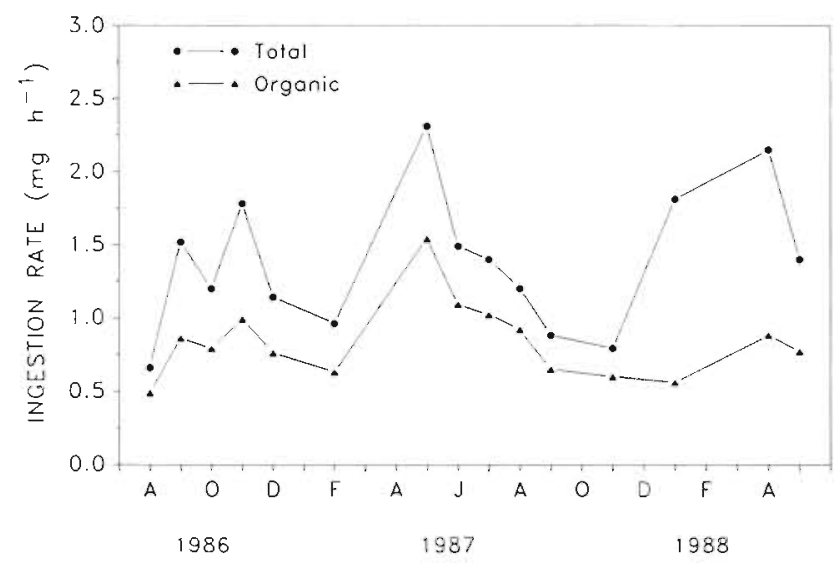

Fig. 4. Modiolus modiolus. Ingestion rate Itotal particulate matter (TPM) and particulate organic matter (POM)] for a mussel of $2 \mathrm{~g}$ dry tissue weight

to $93.3 \%$ in September 1987 , with a mean of $76.5 \%$ for a mussel of $2 \mathrm{~g}$ dry tissue weight (Fig. 5). Only 2 low values were recorded during the entire period of the study $153.2 \%$ and $50.3 \%$ for October and November 1986, respectively).

Absorption efficiency was usually independent of body size, as evidenced by lack of significant regressions for all but 2 months (July and September of 1987). When all the data for $\mathrm{AE}$ were pooled in one regression equation, it was not significant at $\mathrm{p}=0.05\left(F_{1,186}=\right.$ 0.048).

Absorption rate $(A R)$ was calculated as the product of $\mathrm{AE}$ and IR.

\section{Oxygen uptake}

Highly significant linear regressions of $\log \mathrm{VO}_{2}$ against $\log$ (dry tissue weight) were found in every

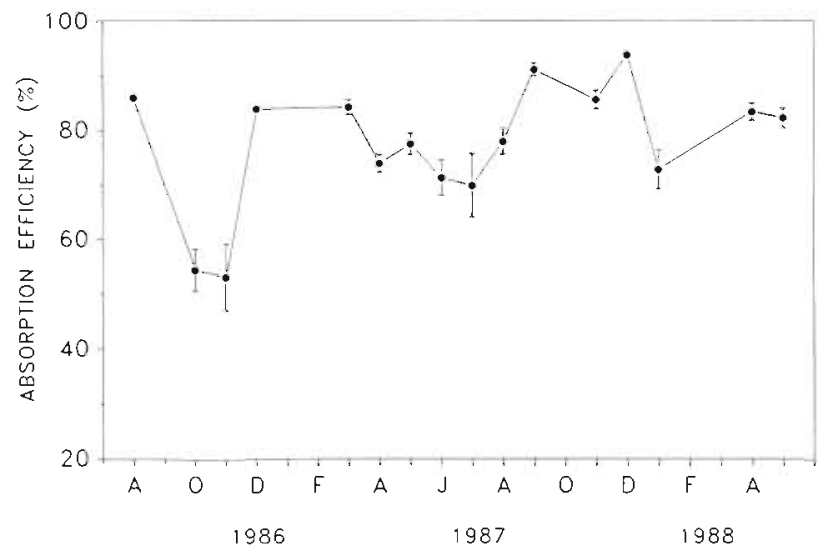

Fig. 5. Modiolus modiolus. Absorption efficiency. Values are monthly means \pm SE. When no SE bars are shown, they were smaller than the symbols 
Table 2. Modiolus modiolus. Regressions of oxygen uptake $\left(\mathrm{mlO} \mathrm{O}_{2} \mathrm{~h}^{-1}\right.$ ) aģainst dry weight $(\mathrm{g})$ for different dates. Regression equations are of the form $Y=a W^{b}$, where $Y=$ oxygen uptake and $W=$ dry weight. The statistic $F$ tests the significance of the difference between $b$ and zero. ${ }^{a}$ All $F$ values significant at $p \leq 0.01$

\begin{tabular}{|lrcccr|}
\hline Date & $\mathrm{n}$ & $\mathrm{a}$ & $b$ & $\mathrm{r}$ & $F^{\mathrm{d}}$ \\
\hline Aug 1986 & 9 & 0.279 & 0.72 & 0.96 & 89.9 \\
Oct 1986 & 12 & 0.167 & 0.45 & 0.92 & 52.1 \\
Nov 1986 & 16 & 0.082 & 0.85 & 0.98 & 276.5 \\
Feb 1987 & 15 & 0.053 & 0.87 & 0.88 & 45.7 \\
Mar 1987 & 15 & 0.059 & 0.66 & 0.91 & 61.5 \\
Apr 1987 & 15 & 0.100 & 0.67 & 0.79 & 21.5 \\
May 1987 & 10 & 0.070 & 0.96 & 0.95 & 66.1 \\
Jun 1987 & 14 & 0.180 & 0.62 & 0.92 & 65.8 \\
Jul 1987 & 15 & 0.273 & 0.66 & 0.97 & 213.4 \\
Aug 1987 & 15 & 0.354 & 0.61 & 0.81 & 25.3 \\
Sep 1987 & 13 & 0.203 & 0.71 & 0.76 & 14.9 \\
Nov 1987 & 14 & 0.119 & 0.76 & 0.95 & 102.3 \\
Jan 1988 & 14 & 0.063 & 1.01 & 0.91 & 59.1 \\
Apr 1988 & 14 & 0.043 & 0.87 & 0.78 & 18.5 \\
May 1988 & 14 & 0.103 & 0.72 & 0.88 & 42.8 \\
Pooled data & 205 & 0.123 & 0.68 & 0.68 & 170.1 \\
\hline
\end{tabular}

month ( $p \leq 0.01$ ), and also when the data were pooled in one regression equation (Table 2).

Oxygen uptake presented a clear seasonal pattern characterised by a marked summer peak followed by a rapid decline during the beginning of the fall to reach a minimum in winter (Fig. 6). Oxygen uptake showed no seasonal acclimation to temperature, with which it was strongly correlated (Fig. 7A). There was also a significant relationship between $V \mathrm{VO}_{2}$ and the weight of the gonad (an index of gametogenic state) throughout the year (Fig. 7B).

\section{Ammonia excretion}

The results of linear regression of $\log \mathrm{VNH}_{4}-\mathrm{N}$ against $\log$ (dry weight) indicated that in all months there was a significant relationship at $p \leq 0.01$ (Table 3). Similar results were obtained when the data were pooled in one regression equation. Ammonia excretion followed a similar seasonal pattern to $\mathrm{VO}_{2}$ (Fig. 8), rising abruptly during the spring to reach maximum values in summer during the period of elevated rates of oxygen consumption and higher temperatures. Like $\mathrm{VO}_{2}, \quad \mathrm{VNH}_{4}-\mathrm{N}$ decreased after August, attaining minimum

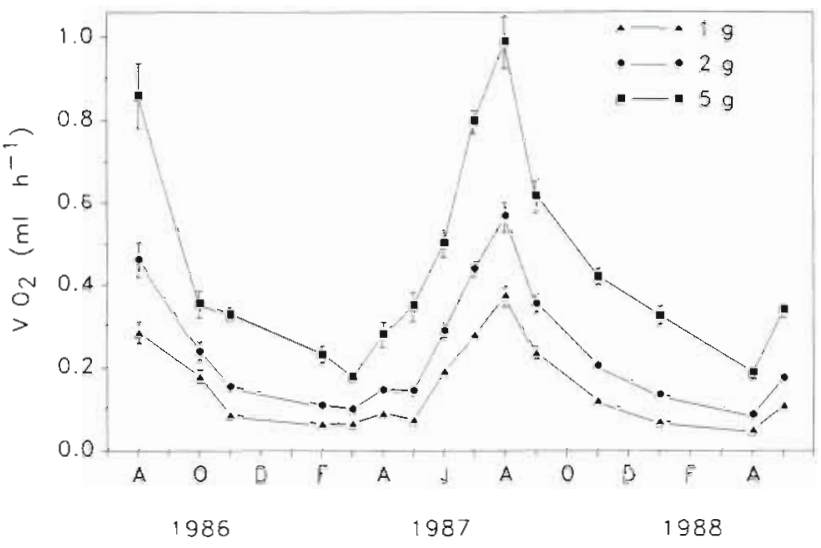

Fig. 6. Modiolus modiolus. Oxygen uptake $\left(\mathrm{VO}_{2}\right)$ in 3 size classes of horse mussel. Values are monthly means \pm SE. When no SE bars are shown, they were smaller than the symbols

values during winter and the beginning of spring. Excretion rate was also correlated with temperature (Fig, 7A) and gonad weight (Fig. 7B).

The ratio between $V \mathrm{O}_{2}$ and $V \mathrm{NH}_{4}-\mathrm{N}(\mathrm{O}: \mathrm{N}$, calculated by atomic equivalents) indicates the proportion of protein relative to lipid and carbohydrate that is catabolised for energy metabolism. A high rate of pro-
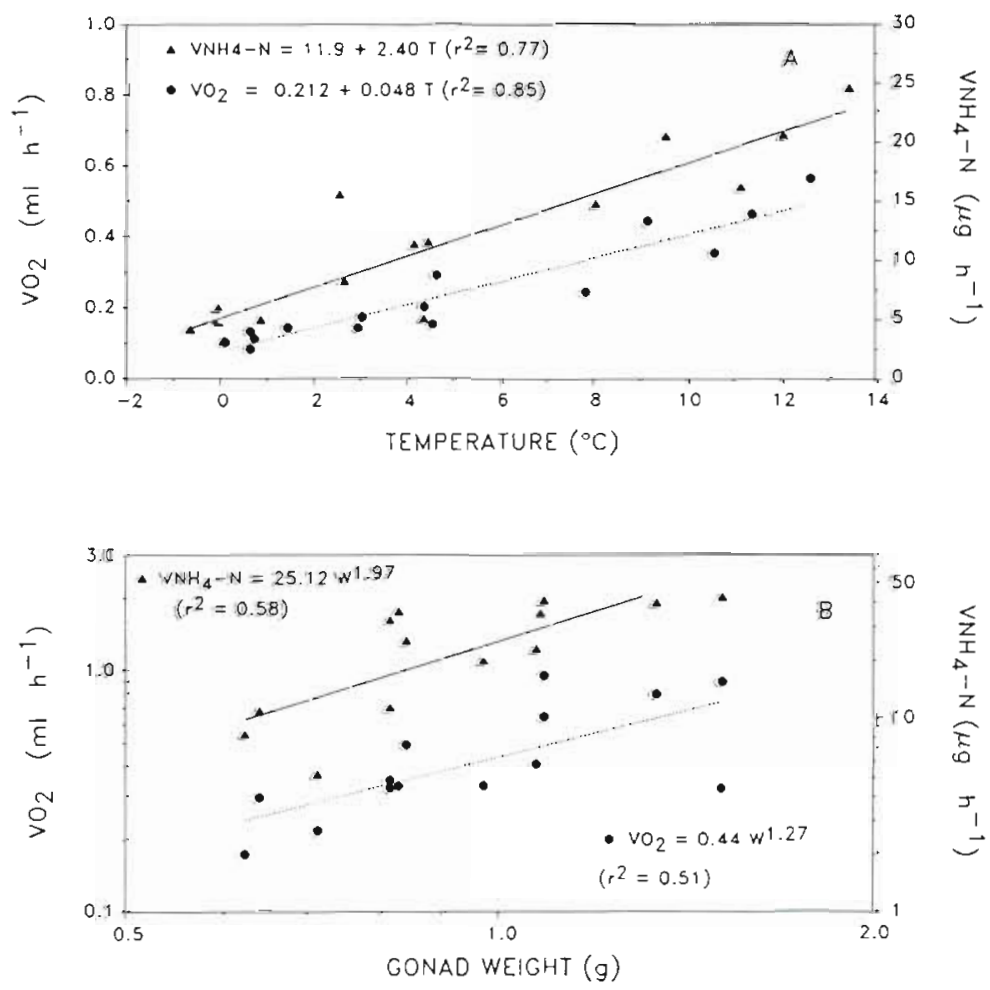

Fig. 7. Modiolus modiolus Regressions of oxygen uptake $\left(\mathrm{mI} \mathrm{h}^{-1}\right.$; and ammonia excretion ( $\left.\mu \mathrm{g} \mathrm{NH}_{4}-\mathrm{N} \mathrm{h}^{-1} ; \mathbf{\Delta}\right)$ against $(\mathrm{A})$ temperature and (B) gonad weight for a $5 \mathrm{~g}$ dry tissue weight mussel 
Table 3. Modiolus modiolus. Regressions of ammonia excre-

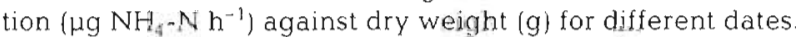
Regression equations are of the form $Y=a W^{b}$, where $Y=$ ammonia excretion and $W=$ dry weight. The statistic $F$ tests the significance of the difference between $b$ and zero. "All $F$ values significant at $p \leq 0.01$

\begin{tabular}{|lrrcrr|}
\hline Date & $\mathrm{n}$ & $a$ & $b$ & $\mathrm{r}$ & $F^{\circ}$ \\
\hline Aug 1986 & 8 & 11.43 & 0.81 & 0.96 & 71.1 \\
Oct 1986 & 10 & 7.89 & 0.87 & 0.99 & 281.4 \\
Nov 1986 & 13 & 2.57 & 0.92 & 0.96 & 137.5 \\
Feb 1987 & 13 & 1.88 & 0.62 & 0.76 & 15.0 \\
Mar 1987 & 14 & 2.16 & 0.83 & 0.89 & 47.7 \\
Apr 1987 & 15 & 2.51 & 0.91 & 0.93 & 86.9 \\
May 1987 & 10 & 8.09 & 0.92 & 0.98 & 218.1 \\
Jun 1987 & 14 & 5.98 & 0.89 & 0.94 & 83.0 \\
Jul 1987 & 15 & 11.97 & 0.74 & 0.96 & 151.8 \\
Aug 1987 & 15 & 16.11 & 0.57 & 0.92 & 67.9 \\
Sep 1987 & 13 & 7.53 & 0.96 & 0.73 & 12.7 \\
Nov 1987 & 14 & 6.38 & 0.79 & 0.92 & 65.8 \\
Jan 1988 & 14 & 3.05 & 0.90 & 0.88 & 42.7 \\
Apr 1988 & 14 & 2.43 & 0.87 & 0.79 & 19.2 \\
May 1988 & 14 & 4.02 & 0.99 & 0.91 & 56.9 \\
Pooled data & 196 & 5.00 & 0.81 & 0.69 & 178.4 \\
\hline
\end{tabular}

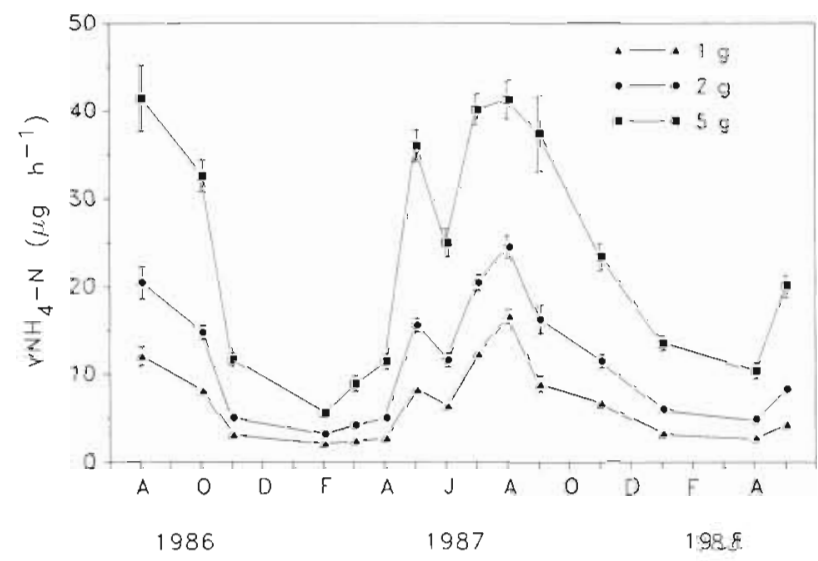

Fig. 8. Modiolus modiolus. Ammonia excretion $\left(V \mathrm{NH}_{4}-\mathrm{N}\right)$ in 3 size classes of horse mussel. Values are monthly means \pm SE. When no SE bars are shown, they were smaller than the symbols

tein relative to lipid and carbohydrate catabolism results in a low $\mathrm{O}: \mathrm{N}$ ratio. The $\mathrm{O}: \mathrm{N}$ ratio for Modiolus modiolus fluctuated around 25, although a higher value $(-52.8)$ was obtained in February 1987 and a lower value $(-11.4)$ was observed in May of the same year (Fig. 9).

\section{Scope for growth and net growth efficiency}

The conversion of the physiological rates into energy equivalents for each month and the subsequent calculation of SFG for a mussel of $2 \mathrm{~g}$ dry tissue weight is

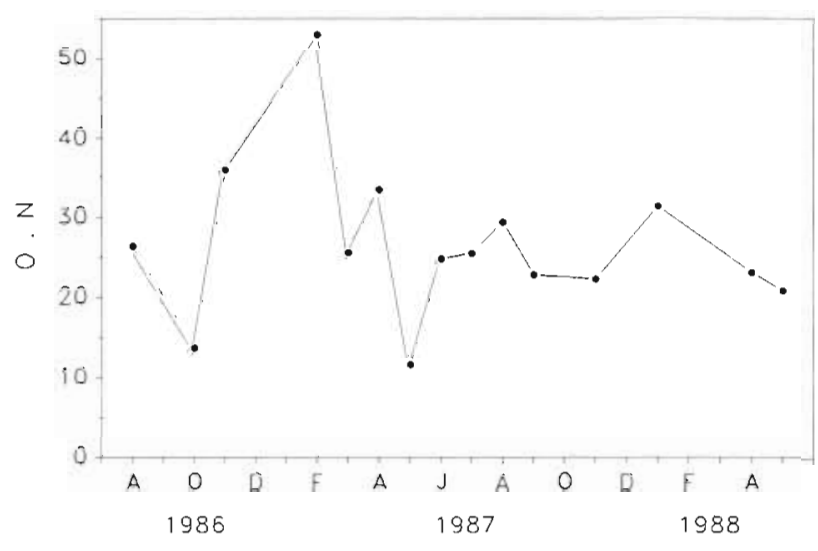

Fig. 9. Modiolus modiolus. Seasonal variation in the atomic ratio of oxygen consumed to the ammonia-nitrogen excreted in a horse mussel of $5 \mathrm{~g}$ dry tissue weight

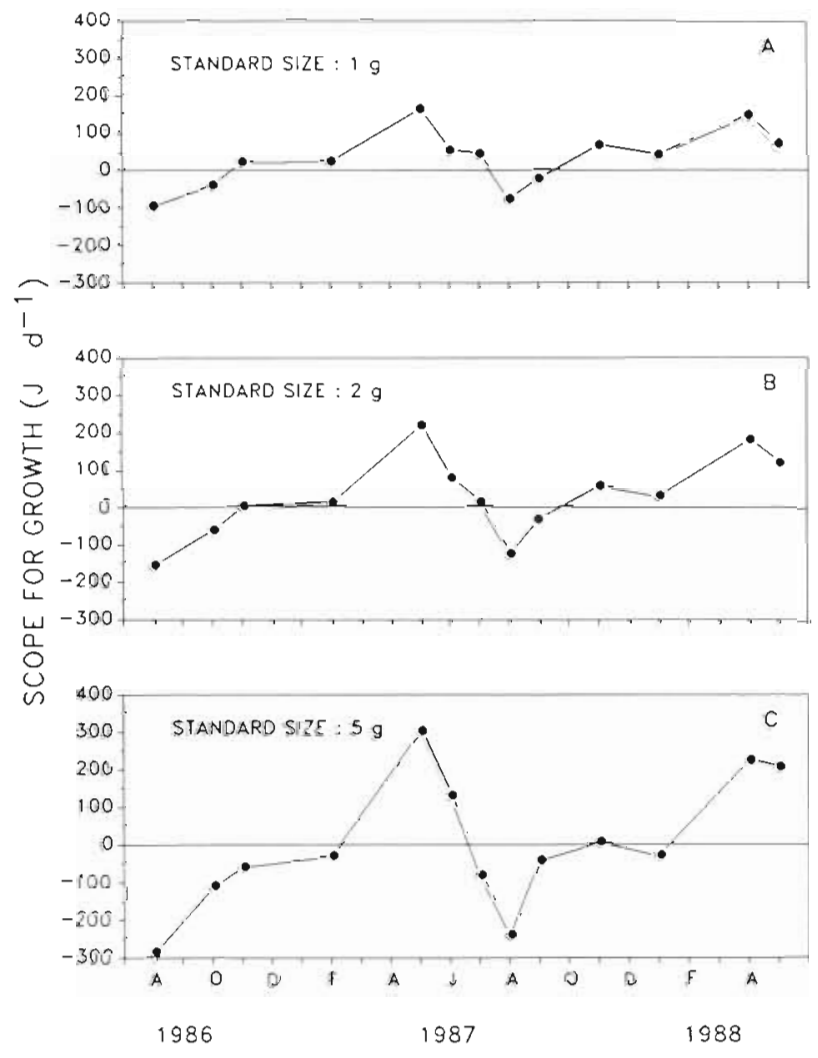

Fig. 10. Modiolus modiolus. Seasonal cycle in the scope for growth (SFG) for 3 size classes of horse mussel

presented in Table 4 . Scope for growth in 3 size classes of Modiolus modiolus at intervals over $2 \mathrm{yr}$ is plotted in Fig. 10. During the spring, SFG was higher in both years of the study and in all 3 size classes investigated. There was a considerable decrease in SFG from May to August, and negative values were reported in August and September in both years (Fig. 10A, B). This was most apparent in larger mussels $(5 \mathrm{~g}$ dry tissue 
Table 4. Modiolus modiolus. Scope for growth for a standard mussel of $2.0 \mathrm{~g}$ dry weight. See 'Material and methods' for details of calculations

\begin{tabular}{|c|c|c|c|c|c|c|c|c|c|c|c|c|c|}
\hline Date & $\begin{array}{c}\text { TPM } \\
\left(m g l^{-1}\right)\end{array}$ & $\left(\mathrm{mg} \mathrm{l}^{-1}\right.$ & $\left(\mathrm{J} \mathrm{l}^{-1}\right)$ & $\begin{array}{c}\text { Clearance } \\
\text { rate } \\
\left(1 \mathrm{~d}^{-1}\right)\end{array}$ & $\begin{array}{r}\text { Inge } \\
\text { rate } \\
\left(\mathrm{mg} \mathrm{d}^{-1}\right)\end{array}$ & $\begin{array}{l}\text { stion } \\
\text { (org.) } \\
\left(\mathrm{J} \mathrm{d}^{-1}\right)\end{array}$ & $\begin{array}{c}\text { Absorption } \\
\text { efficiency } \\
(\%)\end{array}$ & $\begin{array}{r}\text { Abso } \\
r a \\
\left(\mathrm{mg} \mathrm{d}^{-1}\right.\end{array}$ & $\begin{array}{l}\text { rption } \\
\left(\mathrm{J} \mathrm{d}^{-1}\right)\end{array}$ & $\begin{array}{c}\text { Oxygen } \\
\text { uptake } \\
\left(\mathrm{J} \mathrm{d}^{-1}\right)\end{array}$ & $\begin{array}{l}\text { Ammonia } \\
\text { excretion } \\
\left(\mathrm{J} \mathrm{d}^{-1}\right)\end{array}$ & $\begin{array}{l}\mathrm{SFG} \\
\left(\mathrm{J} \mathrm{d}^{-1}\right)\end{array}$ & $K_{2}$ \\
\hline Aug 1986 & 0.85 & 0.63 & 4.89 & 18.7 & 11.8 & 91.5 & 86.0 & 10.1 & 78.7 & 224.0 & 12.2 & -157.5 & -2.00 \\
\hline Sep 1986 & 1.58 & 0.90 & 4.10 & 23.0 & 20.7 & 94.5 & - & - & - & - & - & - & - \\
\hline Oct 1986 & 1.06 & 0.70 & 4.08 & 27.1 & 19.0 & 110.6 & 54.4 & 10.3 & 60.2 & 115.2 & 8.8 & -63.8 & -1.06 \\
\hline Nov 1986 & 1.37 & 0.76 & 4.67 & 31.2 & 23.7 & 145.7 & 53.1 & 12.6 & 77.4 & 73.2 & 3.0 & 1.2 & 0.02 \\
\hline Dec 1986 & 1.13 & 0.75 & 2.47 & 24.2 & 18.2 & 59.9 & 83.9 & 15.3 & 50.3 & - & - & - & - \\
\hline Feb 1987 & 0.99 & 0.65 & 3.14 & 23.3 & 15.1 & 73.1 & 86.8 & 13.1 & 63.5 & 51.2 & 1.9 & 10.4 & 0.16 \\
\hline May 1987 & 2.04 & 1.36 & 16.48 & 27.1 & $31.4^{\circ}$ & $379.9^{\circ}$ & 77.6 & 24.4 & 294.8 & 68.3 & 9.3 & 217.2 & 0.74 \\
\hline Jun 1987 & 1.05 & 0.77 & 9.13 & 34.1 & 26.2 & 311.2 & 71.4 & 18.7 & 222.2 & 139.1 & 6.9 & 76.2 & 0.34 \\
\hline Jul 1987 & 0.90 & 0.66 & 9.05 & 37.2 & 24.6 & 336.7 & 70.0 & 1.7 .2 & 235.7 & 212.0 & 12.2 & 11.5 & 0.05 \\
\hline Aug 1987 & 0.89 & 0.68 & 6.43 & 32.4 & 22.0 & 208.3 & 78.0 & 17.2 & 162.5 & 275.0 & 14.6 & -127.1 & -0.78 \\
\hline Sep 1987 & 0.84 & 0.62 & 6.51 & 25.2 & 15.6 & 164.0 & 91.2 & 14.2 & 149.6 & 171.3 & 9.6 & -31.3 & -0.21 \\
\hline Nov 1987 & 0.70 & 0.53 & 6.87 & 27.1 & 14.4 & 186.3 & 85.7 & 12.3 & 159.7 & 98.1 & 6.8 & 54.8 & 0.34 \\
\hline Jan 1988 & 1.83 & 0.57 & 5.49 & 23.8 & 13.5 & 130.4 & 72.9 & 9.8 & 95.1 & 63.9 & 3.5 & 27.7 & 0.29 \\
\hline Apr 1988 & 1.57 & 0.75 & 9.47 & 32.9 & $21.0^{\alpha}$ & $264.7^{d}$ & 83.5 & 20.6 & 221.0 & 40.0 & 2.8 & 178.2 & 0.81 \\
\hline May 1988 & 1.25 & 0.81 & 10.85 & 26.9 & $18.5^{\circ}$ & $248.0^{\circ}$ & 82.4 & 18.0 & 204.4 & 83.4 & 4.9 & 116.1 & 0.57 \\
\hline
\end{tabular}

weight), in which SFG was negative during summer, fall and early winter (Fig. 10C), with values as low as $-300 \mathrm{~J} \mathrm{~d}^{-1}$ During winter, SFG was very close to zero, the available energy being just adequate for the maintenance of the basic physiological processes.

Net growth efficiency for Modiolus modiolus (Table 4) fluctuated widely according to season, with values as low as -2.0 during summer (August 1986) and as high as 0.81 during spring (April 1988). As with SFG, the lower values for $K_{2}$ were associated with low $\mathrm{CR}$, high $\mathrm{VO}_{2}$, high temperature and low quality of the food supply. Conversely, higher values of $K_{2}$ were associated with low $\mathrm{VO}_{2}$, low temperature and an energy-rich food supply provided by the phytoplankton.

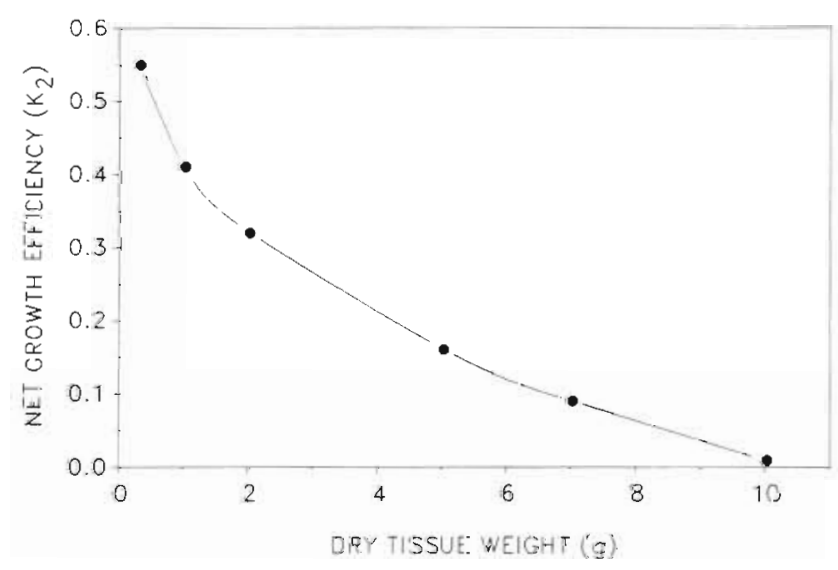

Fig. 11. Modiolus modiolus. Net growth efficiency $\left(K_{2}\right)$ (based on regressions of pooled data of each physiological variable) vs dry tissue weight bloom. Net growth efficiency was clearly dependent on body size (Fig. 11), ranging between 0.55 and 0.02 for mussels of 0.3 and $10 \mathrm{~g}$ dry weight, respectively.

\section{Correlation analysis and multiple regression}

Clearance rate was not correlated with any of the environmental variables, and the correlation between $C R$ and AR was attributable to autocorrelation of these 2 physiological rates (Table 5). Multiple regression analysis between $C R$ and the environmental variables showed that no variables were entered at $p \leq 0.05$. Similar results were obtained for $A E$, where no physiological or environmental variable was entered at $p \leq 0.05$ In contrast, AR was correlated with many of the environmental variables measured by Navarro \& Thompson (1995), showing that there was a good relationship between AR and the nutritive components of the seston (Table 5). The variation in AR was best explained by the model which included POM, particle volume (PartV) and chlorophyll a (CHLA) as independent variables, accounting for $97 \%$ of the variation (Table 6).

Oxygen uptake was positively correlated with temperature $(r=0.93)$ and $V \mathrm{NH}_{4}-\mathrm{N}(\mathrm{r}=0.88)$, and negatively correlated with PartV $(r=-0.85)$ and particulate inorganic matter (PIM) ( $r=-0.63)$. Temperature alone explained $86 \%$ of the total variance in $\mathrm{VO}_{2}$, and when PartV was included in the model, the proportion increased to $92 \%$ (Table 6 ). All the other independent variables accounted for a very small additional percentage. 
Table 5. Pearson product-moment correlation coefficients between physiological and environmental variables. " $\mathrm{p}<0.05 ; \cdot{ }^{\mathrm{p}}<<$ 0.01. Number of cases in parentheses. CR: clearance rate; TIR: total ingestion rate; AE: absorption efficiency; $V O$; oxygen uptake rate; $V \mathrm{NH}_{4}$ : ammonia excretion; SFG: scope for growth; $K_{2}$ : net growth efficiency; TPM: total particulate matter; PIM: particulate inorganic matter; CHLA: chlorophyll a; PON: particulate organic nitrogen; POC: particulate organic carbon; LIP: lıpid; CHO: carbohydrate; PartN: particulate nitrogen; PartV: particulate volume; TEMP: temperature; FM: food material; FIDX: food index. See Navarro \& Thompson (1995) for more information regarding environmental variables

\begin{tabular}{|c|c|c|c|c|c|c|c|c|c|c|c|c|c|c|c|c|c|c|c|c|c|}
\hline & $C R$ & TIR & $A . E$ & $A R$ & $\mathrm{VO}_{2}$ & $\mathrm{NNH}_{4}$ & SFG & $K_{2}$ & TPM & POM & PIM & CHLA & PON & $\mathrm{POC}$ & LIP & $\mathrm{CHO}$ & PartN & PartV & TEMP & FM & FIDX \\
\hline$C R$ & $\begin{array}{l}1.00 \\
(17)\end{array}$ & $\begin{array}{l}0.39 \\
(17)\end{array}$ & $\begin{array}{r}-0.39 \\
(14)\end{array}$ & $\begin{array}{l}0.56^{\circ} \\
(14)\end{array}$ & $\begin{array}{l}0.06 \\
(13)\end{array}$ & $\begin{array}{l}0.07 \\
(131\end{array}$ & $\begin{array}{l}0.03 \\
(13)\end{array}$ & $\begin{array}{l}0.53 \\
(13)\end{array}$ & $\begin{array}{r}-0.03 \\
(17)\end{array}$ & $\begin{array}{l}0.06 \\
(17)\end{array}$ & $\begin{array}{r}-0.06 \\
(17)\end{array}$ & $\begin{array}{l}025 \\
|16|\end{array}$ & $\begin{array}{l}037 \\
(17)\end{array}$ & $\begin{array}{l}0.47 \\
(17)\end{array}$ & $\begin{array}{l}0.34 \\
(16)\end{array}$ & $\begin{array}{l}0.38 \\
(16)\end{array}$ & $\begin{array}{l}0.23 \\
(10)\end{array}$ & $\begin{array}{r}-0.47 \\
(10)\end{array}$ & $\begin{array}{l}0.04 \\
(17)\end{array}$ & $\begin{array}{l}0.39 \\
116)\end{array}$ & $\begin{array}{l}0.28 \\
(16)\end{array}$ \\
\hline TIR & & $\begin{array}{l}1.00 \\
(17)\end{array}$ & $\begin{array}{r}-0.40 \\
(14)\end{array}$ & $\begin{array}{l}0.55^{\circ} \\
(14)\end{array}$ & $\begin{array}{r}-0.52 \\
(13)\end{array}$ & $\begin{array}{r}-0.31 \\
(13)\end{array}$ & $\begin{array}{l}013 \\
\text { (13) }\end{array}$ & $\begin{array}{l}063^{\circ} \\
(13)\end{array}$ & $\begin{array}{l}0.91{ }^{\circ} \\
(17)\end{array}$ & $\begin{array}{l}0.75 \cdots \\
(17)\end{array}$ & $\begin{array}{l}0.86^{\circ} \\
(17)\end{array}$ & $\begin{array}{c}0.57^{\prime} \\
(16)\end{array}$ & $\begin{array}{l}0.32 \\
(17)\end{array}$ & $\begin{array}{l}0.40 \\
(17)\end{array}$ & $\begin{array}{l}0.28 \\
\{16\}\end{array}$ & $\begin{array}{l}0.45 \\
(16)\end{array}$ & $\begin{array}{l}0.53 \\
(10)\end{array}$ & $\begin{array}{l}0.47 \\
(10)\end{array}$ & $\begin{array}{r}-0.52^{\circ} \\
(17)\end{array}$ & $\begin{array}{l}0.28 \\
(16)\end{array}$ & $\begin{array}{r}-0.26 \\
(16)\end{array}$ \\
\hline $\mathrm{AE}$ & & & $\begin{array}{l}1.00 \\
(17)\end{array}$ & $\begin{array}{l}0.06 \\
(14)\end{array}$ & $\begin{array}{r}-0.04 \\
(15)\end{array}$ & $\begin{array}{r}-0.81 \\
(15)\end{array}$ & $\begin{array}{l}0.56 \\
(13)\end{array}$ & $\begin{array}{l}0.04 \\
(13)\end{array}$ & $\begin{array}{r}-0.34 \\
(17)\end{array}$ & $\begin{array}{r}-0.32 \\
\{17\}\end{array}$ & $\begin{array}{r}-025 \\
(17)\end{array}$ & $\begin{array}{l}0.03 \\
117)\end{array}$ & $\begin{array}{l}009 \\
(17)\end{array}$ & $\begin{array}{r}-0.14 \\
117)\end{array}$ & $\begin{array}{r}-0.05 \\
\{17\}\end{array}$ & $\begin{array}{r}-010 \\
(17)\end{array}$ & $\begin{array}{r}-0.39 \\
(11)\end{array}$ & $\begin{array}{r}-0.02 \\
(11)\end{array}$ & $\begin{array}{r}-0.26 \\
(17)\end{array}$ & $\begin{array}{l}0.05 \\
(17)\end{array}$ & $\begin{array}{l}0.26 \\
(17)\end{array}$ \\
\hline AR & & & & $\begin{array}{l}100 \\
(14)\end{array}$ & $\begin{array}{l}0.12 \\
(13)\end{array}$ & $\begin{array}{l}0.40 \\
(13)\end{array}$ & $\begin{array}{l}0.32 \\
(13)\end{array}$ & $\begin{array}{l}0.40 \\
(13)\end{array}$ & $\begin{array}{l}0.33 \\
(14)\end{array}$ & $\begin{array}{l}0.72 \% \\
(14)\end{array}$ & $\begin{array}{l}007 \\
(14)\end{array}$ & $\begin{array}{l}065^{\circ} \\
(14)\end{array}$ & $\begin{array}{l}072 \cdot " \\
(14)\end{array}$ & $\begin{array}{c}069^{\circ} \\
\text { (14) }\end{array}$ & $\begin{array}{l}\cdot 0.67^{\circ} \\
(14)\end{array}$ & $\begin{array}{c}\cdot 0.60^{\circ} \\
(14)\end{array}$ & $\begin{array}{c}0.42 \\
(9)\end{array}$ & $\begin{array}{c}0.24 \\
(9)\end{array}$ & $\begin{array}{l}0.14 \\
\text { (14) }\end{array}$ & $\begin{array}{l}0.71^{\prime} \\
(14)^{\prime}\end{array}$ & $\begin{array}{r}0.48 \\
|14|\end{array}$ \\
\hline$V \mathrm{O}_{2}$ & & & & & $\begin{array}{l}1.00 \\
(15)\end{array}$ & $\begin{array}{l}0.88^{\circ} \\
(15)\end{array}$ & $\begin{array}{l}0.21 \\
(13)\end{array}$ & $\begin{array}{c}-0.61^{*} \\
(13)\end{array}$ & $\begin{array}{r}-0.36 \\
(15)\end{array}$ & $\begin{array}{l}0.06 \\
(15)\end{array}$ & $\begin{array}{c}-0.63^{\circ} \\
(15)\end{array}$ & $\begin{array}{r}-0.37 \\
(15)\end{array}$ & $\begin{array}{l}023 \\
(15)\end{array}$ & $\begin{array}{l}0.19- \\
(15)\end{array}$ & $\begin{array}{r}-0.22 \\
(15)\end{array}$ & $\begin{array}{r}-0.26 \\
(15)\end{array}$ & $\begin{array}{r}-0.17 \\
(10)\end{array}$ & $\begin{array}{c}-0.85 * \\
(10)\end{array}$ & $\begin{aligned} & 0.93^{\circ} \cdot \\
& (15)\end{aligned}$ & $\begin{array}{l}0.05 \\
(15)\end{array}$ & $\begin{array}{l}0.18 \\
(15)\end{array}$ \\
\hline$V N \mathrm{~N}$ & & & & & & $\begin{array}{l}1.00 \\
(15)\end{array}$ & $\begin{array}{l}0.05 \\
(1.3)\end{array}$ & $\begin{array}{r}-0.49 \\
(13)\end{array}$ & $\begin{array}{r}-0.14 \\
(15)\end{array}$ & $\begin{array}{l}0.27 \\
(15)\end{array}$ & $\begin{array}{r}-0.46 \\
(15)\end{array}$ & $\begin{array}{r}-0.13 \\
(15)\end{array}$ & $\begin{array}{l}048 \\
(15)\end{array}$ & $\begin{array}{l}0.45 \\
\{15\}\end{array}$ & $\begin{array}{l}0.03 \\
(15)\end{array}$ & $\begin{array}{r}-0.02 \\
(15)\end{array}$ & $\begin{array}{r}-015 \\
(10)\end{array}$ & $\begin{array}{r}-0.61 \\
(10)\end{array}$ & $\begin{array}{l}0.89^{\circ} \\
(15)\end{array}$ & $\begin{array}{l}0.30 \\
(15)\end{array}$ & $\begin{array}{l}0.32 \\
(15)\end{array}$ \\
\hline $\mathrm{SFG}$ & & & & & & & $\begin{array}{l}1.00 \\
(13)\end{array}$ & $\begin{array}{l}0.40 \\
(13)\end{array}$ & $\begin{array}{l}0.13 \\
(13)\end{array}$ & $\begin{array}{l}017 \\
(13)\end{array}$ & $\begin{array}{l}006 \\
(13)\end{array}$ & $\begin{array}{l}0.41 \\
(13)\end{array}$ & $\begin{array}{l}060^{\circ} \\
(13)\end{array}$ & $\begin{array}{l}0.48 \\
113)\end{array}$ & $\begin{array}{l}0.44 \\
\lceil 13\rceil\end{array}$ & $\begin{array}{l}0.41 \\
(13)\end{array}$ & $\begin{array}{l}0.43 \\
(9)\end{array}$ & $\begin{array}{c}0.72^{\prime} \\
(9)\end{array}$ & $\begin{array}{r}-0.35 \\
(13)\end{array}$ & $\begin{array}{l}0.43 \\
(13)\end{array}$ & $\begin{array}{r}-0.21 \\
(13)\end{array}$ \\
\hline$K_{2}$ & & & & & & & & $\begin{array}{l}1.00 \\
(13)\end{array}$ & $\begin{array}{l}0.44 \\
(13)\end{array}$ & $\begin{array}{l}0.29 \\
(13)\end{array}$ & $\begin{array}{l}0.42 \\
(13)\end{array}$ & $\begin{array}{l}0.46 \\
(13)\end{array}$ & $\begin{array}{l}0.29 \\
(13)\end{array}$ & $\begin{array}{l}0.34 \\
113\}\end{array}$ & $\begin{array}{l}0.51 \\
(13)\end{array}$ & $\begin{array}{l}0.39 \\
(13)\end{array}$ & $\begin{array}{l}0.40 \\
(9)\end{array}$ & $\begin{array}{c}0.70^{\circ} \\
(9)\end{array}$ & $\begin{array}{r}-0.61 \\
(13)\end{array}$ & $\begin{array}{l}0.36 \\
113)\end{array}$ & $\begin{array}{l}0.03 \\
(13)\end{array}$ \\
\hline
\end{tabular}

Table 6. Modiolus modiolus. Multiple regression statistics for several physiological variables vs subsets of independent variables. " $p \leq 0.05 ; \cdots p \leq 0.01 ; \cdots p \leq 0.001$ See Table 5 tor abbreviations

\begin{tabular}{|c|c|c|c|c|}
\hline Dep. var. & Indep. var & $\mathrm{R}^{2}$ & $\Omega$ & $F$ \\
\hline \multirow[t]{3}{*}{ AR } & $\mathrm{POM}$ & 0.520 & 14 & $12.89^{\circ}$ \\
\hline & PartV & 0.938 & 9 & $45.78 \cdots$ \\
\hline & CHLA & 0.966 & 9 & $47.48^{\circ}$ \\
\hline \multirow[t]{2}{*}{$\mathrm{VO}_{2}$} & TEMP & 0.857 & 15 & $77.78 \cdots$ \\
\hline & PartV & 0.924 & 10 & $42.47^{\cdots} \cdots$ \\
\hline \multirow[t]{2}{*}{$V \mathrm{NH}_{4}$} & TEMP & 0.787 & 15 & $48.14^{\cdots}$ \\
\hline & PartV & 0.898 & 10 & $30.36 \cdots$ \\
\hline \multirow[t]{2}{*}{$\mathrm{SFG}$} & PartV & 0.515 & 9 & $7.44^{\circ}$ \\
\hline & CHLA & 0.631 & 9 & $5.14^{\circ}$ \\
\hline
\end{tabular}

Excretion rate in Modiolus modiolus was highly correlated with temperature and $\mathrm{VO}_{2}$, and the former was the main environmental factor determining $V \mathrm{NH}_{4}-\mathrm{N}$. Multiple regression between $V \mathrm{NH}_{4}-\mathrm{N}$ and the environmental variables showed that $79 \%$ of the total variance in $V \mathrm{NH}_{4}-\mathrm{N}$ was explained by temperature (TEMP) and $90 \%$ by including PartV with TEMP (Table 6).

Scope for growth was correlated ( $\mathrm{p} \leq 0.05$ ) only with 2 environmental variables, particulate organic nitrogen (PON) and PartV, and only with AE among the physiological variables ( $\mathrm{p} \leq 0.05$ ). Multiple regression analysis showed that the best model (PartV + CHLA) explained $63 \%$ of the variation in SFG, whereas PartV alone accounted for $52 \%$ (Table 6 ). The introduction of other variables into the model made very little difference.

\section{Nitrogen balance}

Measurements of PON in Logy Bay and of CR, AE and $\mathrm{VNH}_{4}-\mathrm{N}$ for Modiolus modiolus were made approximately every month to calculate the nitrogen balance (absorbed nitrogen minus excreted nitrogen) as a percentage of the total nitrogen in the tissues of a mussel of $2.0 \mathrm{~g}$ dry weight. The protein content of the dry tissue was measured every month for this purpose (Navarro 1990). It was assumed that the nitrogen content of the protein was $17.2 \%$ by weight (Gnaiger \& Bitterlich 1984). In October 1986 the mussel lost $0.03 \%$ of its body nitrogen per day, and this was the only negative value for nitrogen balance during the entire study (Fig. 12). In spring the mussels gained up to $0.6 \%$ of their body nitrogen per day, largely as a result of low excretion rates and the high concentration of nitrogen in the seston.

\section{DISCUSSION}

Variability in CR has been reported as common in bivalves (Winter 1969, Griffiths 1980, Higgins 1980 , Palmer 1980), and Modiolus modiolus is no exception, 


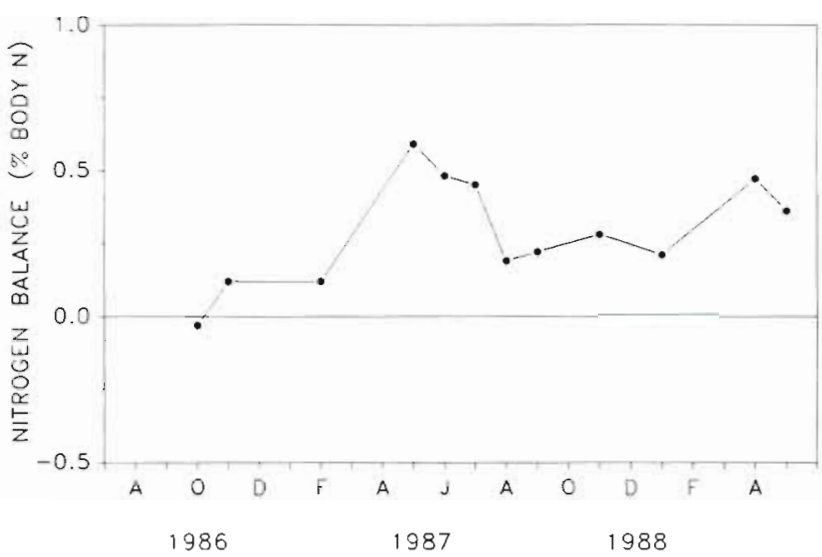

Fig. 12. Modiolus modiolus. Seasonal varlation in the nitrogen balance (as \% of body nitrogen) of a horse mussel of $2 \mathrm{~g}$ dry tissue weight

exhibiling short-term (daily) as well as long-term (seasonal) fluctuations (Figs. 1, 2 \& 3). During spring and early summer $M$. modiolus exhibits a higher and more constant CR (Fig, 1) than during fall and winter, when feeding activity fluctuates greatly (Fig. 2), with some mussels either not filtering or filtering at minimum rates. This behavioural pattern in winter is arhythmic, the initiation of periods of activity and quiescence being apparently random and specific to each experimental mussel, showing no consistency among individuals. These results are similar to those obtained for Crassostrea virginica by Epifanio \& Ewart (1977) and Palmer (1980).

The lowest and most variable CR values observed in Modiolus modiolus, recorded during fall and winter, seem to be associated more with the low nutritive value of the food than with low temperatures, because $\mathrm{CR}$ is high during early spring, when the temperature is approximately $0^{\circ} \mathrm{C}$ but seston quality is high owing to the phytoplankton bloom. Thompson (1984) also reported the ability of Mytilus edulis from Bellevue, Newfoundland, to maintain a high CR at very low temperatures, and Widdows (1976) has shown that this species has a high capacity for acclimation to temperature change.

During spring and early summer the organic component of the seston of Logy Bay consists primarily of living cells, this being reflected in the concentrations of POM, chlorophyll a, PON, particulate organic carbon (POC), lipid and carbohydrate, which are all several times higher than during the rest of the year (Navarro \& Thompson 1995). The intermittent feeding behaviour shown by Modiolus modiolus may represent an adaptive mechanism to conserve energy by reducing the time spent filtering seston of low nutritive value. Worrall et al. (1983) also described a seasonal pattern in $C R$ for 3 different populations of the bivalve Scro- bicularia plana, with reduced values during winter and maxima during summer. Newell \& Bayne (1980) described a similar feeding behaviour for the cockle Cerastoderma edule, in which CR was at a minimum during winter when the organic seston was only half the summer level. Hummel (1985a) found that Macoma balthica quickly reduces its feeding activity when the concentration of available food diminishes, thereby eliminating the high cost of respiration associated with enhanced feeding activity. Riisgard \& Randlov (1981) demonstrated that Mytilus edulis can also adapt to a reduced food supply by decreasing $C R$ considerably, and Widdows et al. (1979) reported high seasonal variability in the CR of Mytilus edulis from the Lynher estuary, some of which was attributable to high particle loads, conditions not observed in Logy Bay.

The differences in CR between seasons observed in Modiolus modiolus are not easily explained, and the relationships between food availability and CR may depend on the nature of the particulate matter. The lowest ingestion rates of total particulate matter (TPM) and POM are observed during winter and the highest rates during spring (Fig. 4), when food availability and nutritional value are greater. These results are consistent with those of Taghon (1981), which suggest that the reduction of feeding rate caused by a decrease in food quality represents an optimal response to poor food conditions.

Although a seasonal pattern can be seen in the CR of Modiolus modiolus (Fig. 3), CR is not correlated with temperature or any other environmental or physiological variable. Similar results have been recorded for Mytilus edulis from Newfoundland (Thompson 1984) and for Cerastoderma edule from England (Newell \& Bayne 1980), although Bayne \& Widdows (1978) described a significant negative correlation between CR and total seston for $M$. edulis over a range of SPM from 7 to $42 \mathrm{mg} \mathrm{l}^{-1}$

Absorption efficiency in Modiolus modiolus is not affected either by seasonal changes in the physiological state of the mussels or in ambient temperature. Similar results were found by Widdows (1978) for Mytilus edulis. During fall 1986, 2 low values were obtained for the AE of $M$. modiolus, at a time when CR and IR were high compared with the fall of 1987 . This may represent a compensatory mechanism to regulate $A R$. The mean AE for the entire study was $76.5 \%$, which is high compared with other studies for various bivalve species (Bayne \& Widdows 1978, review by Bayne \& Newell 1983). However, our results are in good agreement with those of Winter (1969), who also reported very high values of AE (82 to $90 \%)$ in $M$. modiolus, using a different analytical procedure. The high value of AE obtained in the present study is probably attributable to low particle loads (usually below 
$2.0 \mathrm{mg} \mathrm{l}^{-1}$ ), as well as the high digestibility of the food present in this environment. Under these conditions, some organisms are able to compensate by increasing the gut residence time, resulting in a higher AE (Bayne et al. 1984). An ability to increase AE when the food supply decreases has been observed in Mytilus edulis (Thompson \& Bayne 1972, Widdows 1978) and in Mytilus chilensis (Navarro \& Winter 1982).

In keeping with other studies on bivalves (Winter 1969, Thompson \& Bayne 1972, Navarro \& Winter 1982, Navarro 1988), no significant effect of body size was found on AE in Modiolus modiolus, probably because the processes controlling $\mathrm{AE}$, such as ciliary and enzyme activity, are size-independent. Absorption efficiency in horse mussels was not correlated with any environmental variable, and studies on Cerastoderma edule and Mytilus edulis have also shown that AE is not correlated with TPM or POM (Newell \& Bayne 1980, Thompson 1984), although Bayne \& Widdows (1978) found that AE showed a significant correlation with POM (expressed as a proportion of TPM) in Mytilus eduiis from the Lynher estuary, southwest England.

The seasonal changes of $\mathrm{VO}_{2}$ in bivalves have been studied by many authors, with a variety of results. In some cases $\mathrm{VO}_{2}$ has been related to temperature, food availability and/or gametogenesis. Thus Widdows \& Bayne (1971), Widdows (1978), Bayne \& Widdows (1978), and Newell \& Bayne (1980) have recorded a relationship between $V \mathrm{O}_{2}$ and gametogenesis, e.g. high $V_{2}$ values in Mytilus edulis at low temperature in the North Sea, caused by the metabolic demands of gametogenesis. The oxygen uptake of Modiolus modiolus exibits pronounced seasonal changes which generally follow the fluctuations in ambient temperature (Fig. 6). Furthermore, there is a strong correlation ( $p<$ 0.01 ) between $V \mathrm{O}_{2}$ and gonad weight for a mussel of $5 \mathrm{~g}$ dry tissue weight, suggesting that the gonad weight also explains some of the variability in $\mathrm{VO}_{2}$. It is difficult to separate the effects of temperature and gonad weight on $\mathrm{VO}_{2}$ because they vary simultaneously, but the data suggest that the $V_{2}$ cycle is not strictly driven by temperature, and may be intimately linked with the gametogenetic cycle, as has been demonstrated for several other species of molluscs (Bayne \& Newell 1983, Hummel 1985b)

Worrall et al. (1983) also found a relationship between $\mathrm{VO}_{2}$ and temperature in 3 populations of the bivalve Scrobicularia plana, although gametogenic activity also explained a significant part of the variability in $\mathrm{VO}_{2}$. As in Modiolus modiolus (this study), $\mathrm{VO}_{2}$ of the bay scallop Argopecten irradians irradians follows the seasonal changes of water temperature (Bricelj et al. 1987). No correlation between $\mathrm{VO}_{2}$ and gametogenesis was observed by Thompson (1984) or MacDonald
\& Thompson (1986) for the bivalves Mytilus edulis and Placopecten magellanicus, respectively, although a high correlation between $\mathrm{VO}_{2}$ and temperature was obtained for the latter (MacDonald \& Thompson 1986). Shumway et al. (1988) showed that the $V O_{2}$ of the giant scallop Placopecten magellanicus exhibits pronounced seasonal fluctuations which follow the cycles of temperature and gonad maturation, the highest rates being recorded during summer when the gonads are ripe, and the lowest rates during winter when gametogenesis is just beginning.

Although there was a strong positive correlation between $\mathrm{VO}_{2}$ and temperature in Modiolus modiolus (Fig. 7A), negative correlations were obtained between $V_{2}$ and PIM and PartV, suggesting a relationship between food quality and $\mathrm{VO}_{2}$, e.g. an increase in the inorganic component can reduce metabolic costs through reduced feeding activity of the mussels. The inverse relationship between $V \mathrm{O}_{2}$ and $K_{2}$ demonstrates the influence of respiratory losses on the growth rate of the horse mussel.

In most instances, the energy losses associated with ammonia excretion represent less than $5 \%$ of the energy ingested by an individual Modiolus modiolus of $2 \mathrm{~g}$ dry tissue weight (Table 4). Ammonia excretion in the horse mussel is highly correlated with gonad weight, suggesting that mature and developing gametes in the gonad may be responsible for some of the variation in $\mathrm{VNH}_{4}-\mathrm{N}$, as previously reported for some species of bivalves (Bayne \& Widdows 1978 , Widdows 1978, Worrall et al. 1983).

The seasonal cycle in $V \mathrm{NH}_{4}-\mathrm{N}$ by Modiolus modiolus (Fig. 8) is similar to that described previously for $\mathrm{VO}_{2}$, and also follows the temperature cycle. Ammonia excretion is at a minimum in the winter and increases to maximum values in the spring and summer, when the weight of the gonad increases. Thus the seasonal cycle in $V_{N_{H}}-\mathrm{N}$ is not simply temperature dependent, and factors such as reproduction and biochemical energy storage cycles are known to influence the physiological responses of bivalves (Bayne \& Widdows 1978, Widdows 1978, Bayne et al. 1979, Widdows et al. 1979, Bayne \& Newell 1983, Worrall et al. 1983). The relationship between $V \mathrm{NH}_{4}-\mathrm{N}$ and body size in $M$. modiolus is similar to that recorded for other bivalves in which highly significant regressions have been reported (Bayne 1973, Bayne et al. 1976, Bayne \& Scullard 1977, Widdows 1978, Navarro \& Winter 1982. Thompson 1984).

Our values for $O: N(12$ to 53$)$ in Modiolus modiolus are at the low end of the range reported for other mytilids, particularly Mytilus spp. (Bayne \& Thompson 1970, Bayne 1973, Bayne \& Scullard 1977, Widdows 1978, Thompson 1984), although direct comparisons are difficult because $\mathrm{O}: \mathrm{N}$ is sensitive to environmental 
conditions, especially nutrition. According to Widdows (1985), O:N values of approximately 25 to 30 correspond to the maintenance ration, except during the spawning period, when $\mathrm{O}: \mathrm{N}$ tends to be low regardless of nutritional condition. In a study of $M$. modiolus from the Gulf of Maine, Lesser et al. (1994) recorded lower $O: N$ values (range 3 to 16 , measured in August) than those we obtained for Newfoundland mussels, and suggested that protein was being catabolised as an energy substrate. Our highest values (maximum 53) were found in the winter of 1986-87, suggesting some utilisation of carbohydrate and/or lipid reserves, but values this high were not observed during the following winter. During spring and summer, values were lower (12 to 30 ), suggesting less catabolism of lipid and carbohydrate reserves, but the $\mathrm{O}: \mathrm{N}$ data must be interpreted with caution, since the cycles of gametogenesis and energy storage are less discrete in $M$. modiolus than in many bivalves (Navarro 1990), and $\mathrm{O}: \mathrm{N}$ values are closely coupled to these cycles, tending to be low during the spawning period, regardless of food availability (Widdows 1985).

The overall effects of environmental factors on the horse mussel are reflected in SFG and $K_{2}$. The energy demands of respiration $\left(\mathrm{VO}_{2}\right)$ during the summer are higher than the energy absorbed, resulting in negative values for SFG and $K_{2}$ (Table 4). During this time, the temperature in Logy Bay is at its maximum $\left(\sim 14^{\circ} \mathrm{C}\right)$ and $V \mathrm{O}_{2}$ is high. In addition, SPM is lower, resulting in reduced ingestion and absorption rates. On the other hand, the food absorbed during the spring bloom is rich in energy, and this, together with the low $\mathrm{VO}_{2}$ at this time, results in a positive SFG (Fig. 10) and high $K_{2}$ for Modiolus modiolus. Several estimates of SFG have been made for Mytilus edulis, the highest values being observed during summer for populations in southwest England (Bayne \& Widdows 1978, Widdows et al. 1979) and for a population from Newfoundland (Thompson 1984). Lesser et al. (1994) reported values for SFG in $M$. modiolus, but they cannot be compared with ours, since the authors used our $\mathrm{CR}$ and AE data (Navarro 1990) to derive SFG, and the 2 sets of observations are therefore not independent. The lower but still positive SFG values which we recorded in smaller individuals of $M$. modiolus during fall and winter are a consequence of the lower maintenance ration or food requirement during these seasons, which is advantageous to these small horse mussels at a time of the year when food availability is minimal.

Thus the high values for SFG and $K_{2}$ observed in spring for Modiolus modiolus from Logy Bay result from the high nutritional value of the food supplied by the phytoplankton bloom. Similarly, Widdows et al. (1984) provided evidence that variability in the physiological responses of Mytilus edulis is largely deter- mined by certain environmental factors, and the positive effect of the high quality and quantity of particulate material on SFG during the spring bloom is particularly important. Conversely, these authors reported a low SFG when the same mussels were transplanted to a location with poor food conditions.

The value of SFG as a measure of the response of the whole organism is illustrated by data for Modiolus modiolus from the fall of 1986, in which high CR values were recorded, but $A E$ was low. The net result was an estimate of SFG which fitted the seasonal pattern observed in other years. Such compensatory processes are not apparent if one relies exclusively on the measurement of individual physiological rate functions. The seasonal pattern of fluctuation in SFG observed in $M$. modiolus throughout the year is similar in the 3 size classes, although the smaller sizes show prolonged periods with a positive SFG (Fig. 10), largely because of the difference in slopes relating $\mathrm{CR}$ and $\mathrm{VO}_{2}$ to body weight, which favours smaller individuals. Furthermore, according to Rowell (1967) horse mussels from Canadian waters are not sexually mature until they are 4 yr old, which means that small individuals are not subjected to the metabolic demands of gametogenesis, resulting in a higher SFG. Similar results have been found in other species of bivalves by Widdows (1978), MacDonald \& Thompson (1986), Navarro (1988) and Iglesias \& Navarro (1991).

The SFG data suggest that the production of Modiolus modiolus is primarily governed by the amount of phytoplankton in the water, the spring bloom being the most important period (Navarro \& Thompson 1995). The lower values of SFG and $K_{2}$ observed during the rest of the year are associated with food sources containing relatively little chlorophyll a. Our results are very similar to those reported by MacDonald \& Thompson (1986) for Placopecten magellanicus and by Vahl (1980) for Chlamys islandica, in which the higher SFG values observed during the spring are attributable to the high nutritional content of the seston, and to a reduced $\mathrm{VO}_{2}$ associated with low temperature and reduced gametogenesis. Although partially attributable to an increase in $V \mathrm{O}_{2}$, the sharp fall in SFG observed in $M$. modiolus between May and August (Fig. 10) is associated with the disappearance of the phytoplankton bloom, supporting the contention of Bayne \& Newell (1983) that SFG and $K_{2}$ are more dependent on food availability than on temperature.

Modiolus modiolus is a species which is able to compensate physiologically for the poor food conditions occurring in locations such as Logy Bay during a large part of the year. It does this by reducing the time spent filtering during fall and winter, when food availability is low. Conversely, higher values for CR are found during spring and early summer, when the seston is 
mainly composed of phytoplankton. Furthermore, AE values are high for most of the year. Such physiological compensations minimise the periods during which SFG is negative and enable the horse mussel to survive in an environment characterised by an intermittent and often inadequate food supply. Thus the success of a suspension-feeder in maximizing its energy gain will depend on the physiological plasticity which it can show in a given environment.

Acknowledgements. The authors gratefully acknowledge the members of the Ocean Sciences Centre field services unit for collections of horse mussels. We also acknowledge E. Hatfield, D. Steel and S.-H. Lee for their invaluable help during the laboratory and field work. Financial support was provided by an NSERC (Canada) operating grant to R.J.T. and by an International Development Research Centre (Canada) fellowship to J.M.N.

\section{LITERATURE CITED}

Anwar NA, Richardson CA, Seed R (1990) Age determination, growth rate and population structure of the horse mussel Modiolus modiolus. J Mar Biol Ass UK 70:441-457

Bayne BL (1973) Aspects of the metabolism of Mytilus edulis during starvation. Neth J Sea Res 7:399-410

Bayne BL, Hawkins AJS, Navarro E (1988) Feeding and digestion in suspension-feeding bivalve molluscs: the relevance of physiological compensations. Am Zool 28: $147-159$

Bayne BL, Klumpp DW, Clarke KR (1984) Aspects of feeding, including estimates of gut residence time, in three mytilid species (Bivalvia, Mollusca) at two contrasting sites in the Cape Peninsula, South Africa. Oecologia 64:26-33

Bayne BL, Moore MN, Widdows J, Livingstone DR, Salkeld P (1979) Measurements of the responses of individuals to environmental stress and pollution: studies with bivalve molluscs. Phil Trans Roy Soc Lond Ser B 286:563-581

Bayne BL, Newell RC (1983) Physiological energetics of marine molluscs. In: Wilbur KM, Saleuddin ASM (eds) The Mollusca, Vol 4, Physiology, Part 1. Academic Press, London, p 407-515

Bayne BL, Scullard C (1977) An apparent specific dynamic action in Mytilus edulis L. J Mar Biol Ass UK 57:371-378

Bayne BL, Thompson RJ (1970) Some physiological consequences of keeping Mytilus edulis in the laboratory. Helgoländer Wiss Meeresunters 20:526-552

Bayne BL, Widdows J (1978) The physiological ecology of two populations of Mytilus edulis L. Oecologia 37:137-162

Bayne BL, Widdows J, Thompson RJ (1976) Physiological integratıons. In: Bayne BL (ed) Marine mussels, their ecology and physiology. Cambridge University Press, Cambridge, p 261-299

Bricelj VM, Epp J, Malouf RE (1987) Comparative physiology of young and old cohorts of the bay scallop, Argopecten irradians irradians (Lamarck): mortality, growth and oxygen consumption. J Exp Mar Biol Ecol 112:73-91

Brown RA, Seed R (1977) Modiolus modiolus (L.) An autoecological study. In: Keegan BF, O'Céidigh P, Boaden PJS (eds) Biology of benthic organisms. Proc 11th Eur Mar Symp Biol. Pergamon Press, Oxford, p 93-100

Conover RJ (1966) Assimilation of organic matter by zooplankton. Limnol Oceanogr 11:338-354

Elliot JM, Davison W (1975) Energy equivalents of oxygen consumption in animal energetics. Oecologia 19:195-201

Epifanio CE, Ewart J (1977) Maximum ration of four algal diets for the oyster Crassostrea virginica Gmelin. Aquaculture 11:13-29

Gnaiger E (1983) Calculation of energetic and biochemical equivalents of respiratory oxygen consumption. In: Gnaiger E, Forstner H (eds) Polarographic oxygen sensors, Appendix C. Springer-Verlag, Berlin, p 337-345

Gnaiger E, Bitterlich G (1984) Proximate biochemical composition and caloric content calculated from elemental CHN analysis: a stoichiometric concept. Oecologia 62:289-298

Griffiths RJ (1980) Filtration, respiration and assimilation in the black mussel Choromytilus meridionalis. Mar Ecol Prog Ser 3:63-70

Higgins P (1980) Effects of food availability on the valve movements and feeding behaviour of juvenile Crassostrea virginica (Gmelin). II. Feeding rates and behaviour. J Exp Mar Biol Ecol 46:17-27

Hummel H (1985a) Food intake of Macoma balthica (Mollusca) in relation to seasonal changes in its potential food on a tidal flat in the Dutch Wadden Sea. Neth J Sea Res 19:52-76

Hummel H (1985b) An energy budget for a Macoma balthica (Mollusca) population living on a tidal flat in the Dutch Wadden Sea. Neth J Sea Res 19:884-892

Iglesias JIP, Navarro E (1991) Energetics of growth and reproduction in cockles (Cerastoderma edule): seasonal and age-dependent variations. Mar Biol 111:359-368

Lesser MP, Witman JD, Sebens KP (1994) Effects of flow and seston availability on scope for growth of benthic suspension-feeding invertebrates from the Gulf of Maine. Biol Bull 187:319-335

Logan A (1988) A sublittoral hard substrate epibenthic community below $30 \mathrm{~m}$ in Head Harbour Passage, New Brunswick, Canada. Estuar Coast Shelf Sci 27:445-459

MacDonald BA, Thompson RJ (1986) Influence of temperature and food availability on the ecological energetics of the giant scallop Placopecten magellanicus. III. Physiological ecology, the gametogenic cycle and scope for growth. Mar Biol 93:37-48

Navarro JM (1988) The effects of salinity on the physiological ecology of Choromytilus chorus (Molina, 1782) (Bivalvia: Mytilidae). J Exp Mar Biol Ecol 122:19-33

Navarro JM (1990) Influence of the natural food supply on the physiological energetics and biochemical storage cycles of the horse mussel, Modiolus modiolus (Linnaeus). PhD thesis, Memorial University of Newfoundland

Navarro JM. Thompson RJ (1994) Comparison and evaluation of different techniques for measuring absorption efficiency in suspension feeders. Limnol Oceanogr 39: $159-164$

Navarro JM, Thompson RJ (1995) Seasonal fluctuations in the size spectra, biochemical composition and nutritive value of the seston available to a suspension-feeding bivalve in a subarctic environment. Mar Ecol Prog Ser 125:95-106

Navarro JM, Winter JE (1982) Ingestion rate, assimilation efficiency and energy balance in Mytilus chilensis in relation to body size and different algal concentrations. Mar Biol 67:255-266

Newell RIE, Bayne BL (1980) Seasonal changes in the physiology, reproductive condition and carbohydrate content of the cockle Cardium (=Cerastoderma) edule (Bivalvia: Cardiidae). Mar Biol 56:11-19

Ojeda FP, Dearborn JH (1989) Community structure of macroinvertebrates inhabiting the rocky subtidal zone in the Gulf of Maine: seasonal and bathymetric distribution. Mar Ecol Prog Ser 57:147-161 
Palmer RE (1980) Behavioral and rhythmic aspects of filtration in the bay scallop, Argopecten irradians concentricus (Say), and the oyster, Crassostrea virginica (Gmelin). J Exp Mar Biol Ecol 45:273-295

Riisgard HU, Randlov A (1981) Energy budget, growth and filtration rates in Mytilus edulis at different algal concentrations. Mar Biol 61:227-234

Rowell TW (1967) Some aspects of the ecology, growth and reproduction of the horse-mussel Modiolus modiolus. MSc thesis, Queen's University, Kingston, Ontario

Seed R, Brown RA (1977) A comparison of the reproductive cycles of Modiolus modiolus (L.), Cerastoderma (=Cardium) edule (L.) and Mytilus edulis L. in Strangford Lough, Northern Ireland. Oecologia 30:173-188

Shumway SE, Barter J, Stahlnecker J (1988) Seasonal changes in oxygen consumption of the giant scallop, Placopecten magellanicus (Gmelin). J Shellfish Res 7:77-82

Taghon GL (1981) Beyond selection: optimal ingestion rate as a function of food value. Am Nat 118:202-214

Thompson RJ (1984) The reproductive cycle and physiological ecology of the mussel Mytilus edulis in a subarctic, non-estuarine environment. Mar Biol 79:277-288

Thompson RJ, Bayne BL (1972) Active metabolism associated with feeding in the mussel Mytilus edulis L. J Exp Mar Biol Ecol 8:191-212

Vahi O (1980) Seasonal variation in seston and in the growth rate of the Iceland scallop, Chlamys islandica (O. F. Müller) from Balsfjord, $70^{\circ} \mathrm{N}$. J Exp Mar Biol Ecol 48:195-204

This article was presented by J. M. Shick (Senior Editorial Advisor), Orono, Maine, USA
Widdows J (1976) Physiological adaptation of Mytilus edulis to cyclic temperatures. J Comp Physiol 105:115-128

Widdows J (1978) Physiological indices of stress in Mytilus edulis. J Mar Biol Ass UK 58:125-142

Widdows J (1985) Physılogical measurements. In: Bayne BL (ed) The effects of stress and pollution on marine animals. Praeger Publishers, New York, p 3-45

WIddows J, Bayne BL (1971) Temperature acclimation of Mytilus edulis with reference to its energy budget. J Mar Biol Ass UK 51:827-843

Widdows J, Donkin P, Salkeld PN, Clearly JJ, Lowe DM, Evans SV, Thomson PE (1984) Relative importance of environmental factors in determining physiological differences between two populations of mussels (Mytulus edulis). Mar Ecol Prog Ser 17:33-47

Widdows J, Fieth P, Worrall CM (1979) Relationships between seston, available food and feeding activity in the common mussel Mytilus edulis. Mar Biol 50:195-207

Winter JE (1969) Über den Einfluß der Nahrungskonzentration und anderer Faktoren auf Filtrierleistung und Nahrungsausnutzung der Muscheln Arctica islandica und Modiolus modiolus. Mar Biol 4:87-135

Witman JD (1985) Refuges, brological disturbance, and rocky subtidal community structure in New England. Ecol Monogr 55:421-445

Worrall CM, Widdows J, Lowe DM (1983) Physiological ecology of three populations of the bivalve Scrobicularia plana. Mar Ecol Prog Ser 12:267-279

Manuscript first received: May 25, 1994

Revised version accepted: January 30, 1996 